\title{
Turkish High School Students' English Demotivation and Their Seeking for Remotivation: A Mixed Method Research
}

\author{
Cenk Akay ${ }^{1}$ \\ ${ }^{1}$ Faculty of Education, Mersin University, Turkey \\ Correspondence: Cenk Akay, Faculty of Education, Mersin University, Turkey. Tel: 90-507-595-4754. E-mail: \\ cenkakay35@hotmail.com
}

Received: June 12, 2017 Accepted: July 11, 2017 Online Published: July 13, 2017

doi: 10.5539/elt.v10n8p107 URL: http://doi.org/10.5539/elt.v10n8p107

\begin{abstract}
Since Gardner introduced the importance of motivation on Language 2 learning, the concept has been accompanied with three more relevant concepts; amotivation, demotivation and remotivation. This paper mainly focused on high school students' de-motivation and remotivation in English. De-motivation is a set of factors which decreases the motivation level of the learners and re-motivation is an attempt to overcome those de-motivating factors. English learning-teaching process has been a problematic issue for a long time in Turkey. While there are researches focusing on the de-motivating factors in many countries, such a research for Turkish high school students has not been found. This research aimed to fill this research gap and to determine the English demotivation level of the students and the demotivating factors for them and to put forth suggestions to re-motivate the learners. An explanatory design was used as a mixed method research design. The sample was constituted of 579 students. Research results revealed that demotivation level of high school students in English is quite high, their motivation decreases most in high school period. Lack of interest in English, attitude of course teacher, classroom environment and course materials are among demotivating factors. In addition, the students request that, for remotivation, courses should be entertaining, technological tools should be utilized more and frequency of speaking activities should be increased.
\end{abstract}

Keywords: English de-motivation, English re-motivation, high school students

\section{Introduction}

Motivation is regarded as a key for success by both teachers and students. In case of failure, students usually state that they cannot be motivated for learning while teachers express that they could not motivate their students. In other words, lack of motivation is attributed to an important reason for failure. However, it is not so simple, because motivation is, without question, the most complex and challenging issue facing teachers today.' (Scheidecker \& Freeman, 1999: 116; cited in Dörnyei, 2001: 1). Motivation has been widely accepted by both teachers and researchers as one of the key factors that influence the rate and success of second/foreign language (L2) learning (Dörnyei, 1998). Motivation has probably been one of the most often-researched subjects in the fields of psychology and education. The long history of motivation studies in different disciplines, such as motivational psychology, educational psychology, and in particular, language learning, supports the crucial role of motivation in an individual's success in life, and in particular, in his/her academic life (Hassaskhah, Zafarghandi, \& Fazeli, 2015). It is a complex phenomenon and the more its constructs are understood, the better teachers are able to understand the extent to which they can influence it and can cultivate student motivation to varying degrees and play a central role in activating and sustaining it (Nicholson, 2013). Motivation stems from the Latin verb movere which means the notion of movement and it is more or less a mental sustainer that helps people to get things done and helps to understand the behaviours of others (Okon, 2014: 3).

As a theoretical construct, the concept of motivation is used to explain a process which initiates, guides, and maintains goal-oriented treatments (Jahedizadeh, Ghanizadeh \& Ghonsooly, 2016). Therefore, motivation explains why people decide to do something, how hard they are going to pursue it and how long they are willing to sustain the activity (Dörnyei, 2001: 7). Motivation is a considerably important factor in foreign language learning as in other educational areas. According to Al-Sharief (2013), there is a widespread agreement among second language acquisition (SLA) researchers on the importance of motivation to language learning success. Though teachers have subject domain and pedagogical knowledge during learning-teaching process, they exert 
great effort to motivate their learners.

\section{Literature Review}

When the literature is reviewed, it is seen that motivation-related studies are based upon Gardner's studies to a large extent. (Sundqvist \& Olin-Scheller, 2013; Kim, 2015; Kim \& Kim, 2015). Relatively large amount of SLA literature is devoted to motivation as an influential affective variable in language learning from the works of Carrol and then Gardner to the recent studies mainly dominated by Dornyei (Mohammadi, 2014). According to Gardner (1985: 10), motivation refers to a combination of effort plus desire to achieve the goal of learning the language plus favourable attitudes toward learning the language. Dörnyei (2001) states that 'motivation' is related to one of the most basic aspects of the human mind, and most teachers and researchers would agree that it has a very important role in determining success or failure in any learning situation. However, motivation is an umbrella concept in language learning, is influenced by various parameters and has a broader meaning than its lexical meaning. Therefore, while motivation has maintained its conceptual construct through time, it has been supported with three more concepts: amotivation, demotivation and remotivation.

According to Cheon and Reeve (2015), amotivation is a state of motivational apathy in which students harbor little or no reason (motive) to invest the energy and effort that is necessary to learn or to accomplish something. Dörnyei and Ushioda $(2011,139)$ describe 'demotivation' that it will concern specific external forces that reduce or diminish the motivational basis of a behavioural intention or an ongoing action. Remotivation is the process in which student begin to move away from amotivation and demotivation that they suffered during language learning and be motivated again to language learning. This study focuses on demotivation and remotivation in language learning.

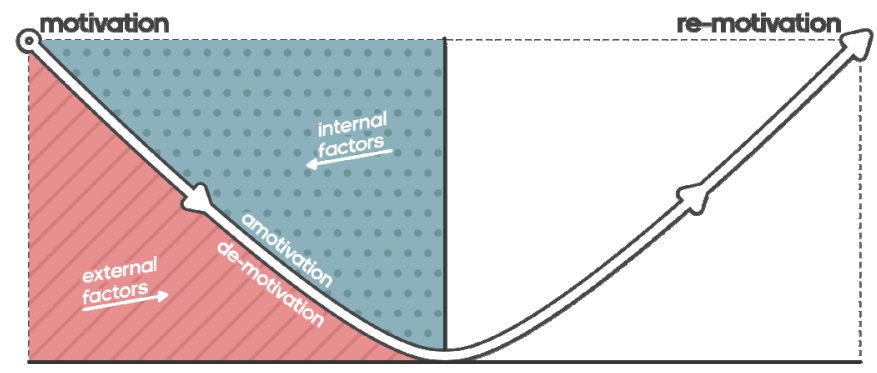

Figure 1. From motivation to remotivation figure

\subsection{Demotivation In Language Learning}

Much of the foreign/second language learning literature is devoted to the research which studies the learning difficulties English Language Learners (ELLs) may come up with. They have attempted to determine the reasons why some students have problems in FL classes (Mohammadi, 2014). In the domain of education and specifically in the field of foreign language learning (EFL), students may face various obstacles such as learning conditions, teachers' methodologies and behaviors, inappropriate materials, or lack of learning facilities or equipment (Jahedizadeh et al., 2016).

Demotivation is one of these key factors. Research on demotivation has been the foci in second language acquisition in recent decades (Li \& Zhou, 2017). For about quarter century, researchers have been working on motivating factors in language learning process and how individuals are motivated as well as focusing on factors that decrease their motivation, or the demotivating factors. (Butt, Khosa, Malghani, Khosa, \& Bukhari, 2016; Jahedizadeh et al., 2016, Al-Sharief, 2013; Challa, 2015; Rashidi, Rahimi, \& Alimorad, 2014; Sundqvist \& Scheller, 2013). It is a relatively new area of investigation, and it has been suggested to involve different mechanisms from those involved in motivation (Kim \& Kim, 2015), and it is accepted as the darker side of the motivation by Hirvonen (2010).

Demotivation has negative effects on language learning processes and outcomes (Kaivanpanah \& Ghasemi, 2011) and it can negatively influence the learner's attitudes and behaviors, degrade classroom group dynamics and teacher's motivation, and result in long-term and widespread negative learning outcomes (Falout, Elwood, \& Hood, 2009). According to Muhonen (2004), demotivation could be regarded as the negative counterpart of motivation and demotives could be regarded as the negative counterparts of motives. Furthermore, a demotivated learner is someone who has lost his or her interest for some reason. It is seen through literature review that 
demotivation-related studies in L2 learning are largely based on Dörnyei's studies. Described by Dörnyei as the decrease of motivation in L2 learning due to external factors, demotivation shows up as effect of varying factors. Dörnyei and Ushioda (2011) mention 9 factors causing demotivation in his study conducted in 1998:

Main demotivating factors identified by Dörnyei;

1). The teacher (personality, commitment, competence, teaching method)

2). Inadequate school facilities (group is too big or not the right level; frequent change of teachers)

3). Reduced self-confidence (experience of failure or lack of success)

4). Negative attitude towards the $L 2$

5). Compulsory nature of L2 study

6). Interference of another foreign language being studied

7). Negative attitude towards L2 community

8). Attitudes of group members

9). Coursebook

As a result, the researches revealed that demotivation in learning English has negative effect on learners, the demotivated learners fail to acquire language skills, and demotivating factors are usually similar but vary from country to country.

\subsection{Remotivation In Language Learning}

Motivation, demotivation, and remotivation are three points on the cycle of language learning experiences which are constantly turning into each other as the result of learners' constant interactions with various influencing factors in the local and broader social contexts (Rashidi et al., 2014). By projecting the responsibility for the students' loss of motivation onto external causes, learners may be better able to limit the motivational damage, in other words, they can be re-motivated which is the process of getting the motivation on-line again (Ushioda, 1998:86). Sahragard and Ansaripour (2014) assert that, one more thing that is needed to be taken into consideration is that remotivating factors, like demotivating factors, are context-specific and all the factors influencing motivation, if dealt with appropriately, may lead to remotivation. The number of studies carried out within this context has increased recently (Guiemi, 2015; Kim, 2015; Sahragard \& Ansaripour, 2014; Falout, 2012). Ushioda (2002) put forth various factors in enabling motivation in L2 learning as a result of his study conducted with learners of French as L2 in Ireland. To conclude, remotivation is an attempt to overcome the problems arising during demotivation and amotivation processes and to restore the decreased motivation level.

Table 1. Language 2 motivating factors

\begin{tabular}{|c|c|c|c|}
\hline \multirow{7}{*}{ 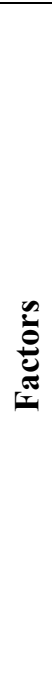 } & Internal Factors & $\begin{array}{l}\text { Personal Circumstances/ } \\
\text { Experience }\end{array}$ & External Factors \\
\hline & Love of L2 & $\begin{array}{l}\text { Length of time speaking L2 since } \\
\text { childhood }\end{array}$ & Good teachers \\
\hline & Love of studying L2 & Having to communicate in L2 & $\begin{array}{l}\text { Enjoyment of class with particular } \\
\text { teacher motivating hard work }\end{array}$ \\
\hline & Personal ability & $\begin{array}{l}\text { One-time personal relationship } \\
\text { with L2 speaker }\end{array}$ & $\begin{array}{l}\text { Competitive class } \\
\text { motivating hard work }\end{array}$ \\
\hline & Effort/hardwork & $\begin{array}{l}\text { Being able to spend more time on } \\
\text { L2 than school }\end{array}$ & \\
\hline & $\begin{array}{l}\text { Being attentive to all } \\
\text { input }\end{array}$ & & \\
\hline & $\begin{array}{l}\text { Better interest in L2 } \\
\text { study than before }\end{array}$ & & \\
\hline
\end{tabular}




\subsection{Research Gap And Aim Of The Study}

As English has become more and more important as an international language, in most countries around the world, large numbers of students are being required to learn it through compulsory programs in schools and universities (Trang \& Baldauf, 2007). English language has got its own international position all over the world. It plays as a basic requirement and tops most priority for the student in schools, colleges and universities (Mirza, Khatoon, \& Lohar, 2016). For that reason, English learning and acquisition processes have been spotlighted by the researchers. Literature review shows that demotivation studies in EFL have been done in many countries (France, Ireland, Taiwan, South Korea, Japan, Pakistan, Iran, etc.) while suggestion studies are conducted for remotivation. However, there is no study in Turkey which focuses on demotivation processes of English learners, specifying demotivating factors and developing suggestions for remotivation. As a result of searching with L2 related "demotivation" keyword in national thesis center, there is only one master's thesis by Birinci (2015) which is about demotivation of prospective English teachers during training them while no research could be found in Google Scholar search about demotivation of high school students in L2. However, it is known that there are problems in both teaching English and students' acquisition of language skills in Turkey (Haznedar, 2010; Paker, 2012; Ișık, 2008; Acat \& Demiral, 2002; Gökdemir, 2005). In his article "Why can't we teach a foreign language (English) in Turkey and why can't our students learn English well enough to interact?", Paker (2002) states that this issue is questioned by most people in many settings but cannot be answered clearly by anyone, and students can't interact in English at the beginner level though they have English classes, as of the publication date of the article, from $4^{\text {th }}$ grade to the end of high school and even at university. Presenting an analysis and a solution for this problem in terms of the student who is the main subject of this problem was seen as a research gap and it was decided to carry out the research. According to Kaivanpanah and Ghasemi (2011), successful language learning requires a serious attention to and plans for dispelling demotivating factors. Any failure to learn a second language may be largely due to the existence of demotivating factors on the part of learners. Mirza et al. (2016) assert that many researchers of L2 teaching and learning have given more emphasis on the motivation of learners or L2 motivation only. But L2 motivation is inadequate for non-native learners and ESL learning problems. Although demotivation has been long researched, its importance in second language learning has been identified very recently. Now it is considered as an important factor in L2 learning.

High school students are particularly included in research group. When the researches done up to now are reviewed, it can be said that as the age increases from primary school to high school in compulsory education, L2 motivation decreases, in other words, students begin to get demotivated. In terms of changes in motivation, research has revealed that L2 learning motivation decreases with age among elementary and high school students (Kim \& Kim, 2015). However, few studies have thus far focused on demotivation among high school students; furthermore, few studies have addressed both demotivators and remotivators within the same sample (Song \& Kim, 2017). In light of this information, it is known that demotivation causes problems in learning English for the high school students. As a result, the purpose of the research is to determine the demotivation levels of high school students and sub-factor distributions causing demotivation, to examine their demotivation according to various variables and to find paths for remotivation according to the students' opinions. "What is the demotivation level of high school students in English and what are the suggestions of paths for remotivation according to students' opinions?" is the main problem of the research. The sub-problems of the research were formed as follows:

1). What is the demotivation level of the high school students?

2). Is there any significant difference depending on various variables (gender, grade, type of school) in terms of students' demotivation?

3). What do the students think about de-motivating factors and paths for re-motivation?

\section{Methodology}

Explanatory sequential pattern based mixed method was employed in the research. Creswell's $(2015,15)$ reasons for preferring mixed method was taken into account in favouring mixed method in this research and each stage of the research was carried out by following Creswell's mixed method processes. Prerequisite factors to employ mixed method are as follows:

- $\quad$ Obtain two different perspectives, one drawn from quantitative data and one drawn from open-ended data (qualitative data),

- Obtain a more comprehensive view and more data about the problem, 
- $\quad$ Add to instrument data (quantitative information) details about the setting, place and context of personal experiences (qualitative information)

When the prerequisite factors above are taken into consideration, mixed approach was favored because of the need to have access to a more comprehensive view about demotivation from the perspective of quantitative-qualitative data and the role of the conversion of students' personal experiences towards demotivation through both quantitative and qualitative data collection. Explanatory sequential design, one of the mixed method designs, was used in the study. The intent of the explanatory sequential design is to study a problem by beginning with a quantitative strand to both collect and analyze data, and then to conduct qualitative research to explain the quantitative results (Creswell, 2015: 38).

Phase 1

Phase 2

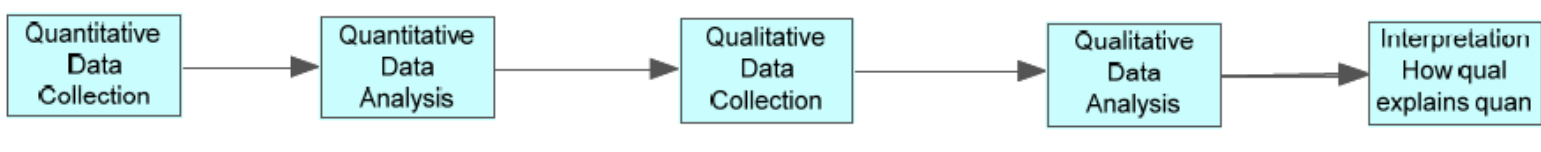

Procedures

Students

$N=579$

Data collection

Products

Database
Procedures

Input into software

Descriptive results

Inferential results

Products

Statistical results

Significance results

\section{Procedures}

Students

Teachers

$N(\mathrm{~S})=84$

\section{Procedures}

Transcribing data

Content Analysis

Coding

Sub-coding

Products

List of quotes, codes

sub-codes, themes

Figure 2. The Explanatory sequential mixed method design (This figure was inspired by Creswell's (2015) the explanatory sequential mixed method design)

\subsection{Procedure of the Research}

In the first stage of the study, the English demotivation scale, a quantitative data collection tool, was applied to determine the demotivation levels of high school students. The results of the scale were then analyzed and it was found that the students' demotivation levels were high, and the second stage of the research was initiated. In this context, English teachers at these schools were requested to apply this data collection tool to demotivated students. Then, the findings obtained from quantitative and qualitative data were tried to be interpreted. Within the scope of the mixed method, different viewpoints which can not be obtained through quantitative data were tried to be taken.

\subsection{Sampling Procedure}

Quantitative data of the research were selected by random sampling method and it was comprised of 601 students from the state high schools in Mersin, Turkey. However, the data of the 22 students who showed extreme values in the normality tests and delivered incomplete forms were extracted before the analysis; therefore, quantitative data were obtained from a group of 579 students in 2016. The quantitative data research group is given in the table below.

Table 2. Features of the sample group

\begin{tabular}{llll}
\hline & & $\mathbf{f}$ & $\mathbf{\%}$ \\
\hline \multirow{3}{*}{ Gender } & Female & 201 & 34.7 \\
\cline { 2 - 4 } & Male & 378 & 65.3 \\
\cline { 2 - 4 } & Total & $\mathbf{5 7 9}$ & $\mathbf{1 0 0}$ \\
\hline \multirow{3}{*}{$9^{\text {th }}$ grade } & 191 & 33 \\
\cline { 2 - 4 } & $10^{\text {th }}$ grade & 141 & 24.5 \\
\hline
\end{tabular}




\begin{tabular}{llll}
\hline Grade & $11^{\text {th }}$ grade & 188 & 32.5 \\
\cline { 2 - 4 } & $12^{\text {th }}$ grade & 59 & 10.2 \\
\cline { 2 - 4 } & Total & $\mathbf{5 7 9}$ & $\mathbf{1 0 0}$ \\
\hline \multirow{3}{*}{ Type of High School } & General High school & 412 & 71.2 \\
\cline { 2 - 4 } & Vocational High school & 167 & 28.8 \\
\cline { 2 - 4 } & Total & $\mathbf{5 7 9}$ & $\mathbf{1 0 0}$ \\
\hline
\end{tabular}

The qualitative data collection tool was based on the selection of the demotivated students by English teachers through purposeful sampling method. Qualitative data were collected from 84 students. It can be seen in Table 3 that 579 students constituted the sample group of quantitative data and 84 students formed the sample group of qualitative data.

Table 3. Distribution of the sample group

\begin{tabular}{lll}
\hline & Data Collection Tools & Students \\
\hline Quantitative Data & Personal Information Form & 579 \\
\cline { 2 - 3 } & Scale & 579 \\
\hline Qualitative Data & Open-Ended Questions Form & 84 \\
\hline
\end{tabular}

\subsection{Data Collection Tools}

Quantitative and qualitative data collection tools were employed in the research. The English De-Motivation Scale (EDS) developed by Ünal and Yanpar (2016) was used as quantitative data tool. The results of the exploratory factor analysis indicated that the scale has one factor having a four-subcomponent factorial structure with 20 items. The subcomponents of the scale are 1) teacher characteristics, 2) lack of interest towards English and English classes, 3) class environment and class materials, and 4) experience of failure. According to the researchers, this scale prepared for university students can be applied on those attending primary and high education as well. First of all, for the reliability of the quantitative data collection tool used in the research, Cronbach-Alpha internal-consistency coefficients of the existing scale were calculated one more time particular to this research. Table 4 shows that entire scale's Cronbach-Alpha internal-consistency coefficient is over 0.70 and the data collection tool is reliable.

Table 4. Cronbach-alpha coefficients of the scale

\begin{tabular}{lll}
\hline & $\begin{array}{l}\text { Cronbach-Alpha } \\
\text { Coefficient }\end{array}$ & $\begin{array}{l}\text { The current Cronbach-Alpha } \\
\text { Coefficient }\end{array}$ \\
\hline English Demotivation Scale (EDS) & .91 & .85 \\
\hline$\alpha>, 70$. & &
\end{tabular}

An open-ended question form as a qualitative data collection tool was developed for students. While developing the open-ended questions in the form, 3 teaching staff members in the Department of Education Curriculum and Instruction graduated from the Department of Foreign Language Education and an instructor in the Department of Foreign Language Education and 2 teachers with at least 5 years of teaching experience in high education institutions were consulted.

\subsection{Validity and Reliability of the Research}

For the reliability of the research, the researcher has a 12-year experience of teaching English which is enough to recognize the problems during English learning process, and opinions of English teachers at the schools where data were collected from were received. In terms of the validity, the validity of the data collection tools was ensured during the scale development process by the researchers who developed the tools. However, the appropriateness of these data collection tools for this research was determined after conducting the interviews 
with 3 field experts. While two of these field experts were Curriculum and Instructional expert, the other one was from ELT department expert. In order to achieve external reliability (verifiability), on the other hand, Miles Huberman inter-coder reliability score was calculated for coder consistency in the process of qualitative data analyses. Miles-Huberman analysis revealed these scores; $83 \%$ for the first question, $81 \%$ for the second question, $87 \%$ for the third question, $88 \%$ for the fourth question and $80 \%$ for the fifth question. According to this anlysis if the score is greater than $80 \%$ inter-coder reliability is considered as acceptable.

\subsection{Data Analysis}

Data analysis was done in two ways: quantitative and qualitative. In order to decide which parametric or non-parametric tests to be performed before quantitative data analysis, the data was subjected to the normality test. SPSSv21 was used for the analysis of the data collected. As it is stated in the literature, there are types of methods to check the normality of the data. These are, Kolmogorov Smirnov value (if the sample size is $>30$ ), standardized skewness and kurtosis values, descriptive statistics and coefficient of variability values as supportive data. In this research, skewness and kurtosis values were taken into account to test normality and descriptive statistics with coefficient of variability values were presented to support the normality test values. The normality test values are given in Table 5 .

Table 5. Normality test of distribution for EDS data

\begin{tabular}{lllll}
\hline & & Statistics & Standard Error & Values \\
\hline \multirow{3}{*}{ EDS } & Skewness & -.272 & .102 & -2.666 \\
& Kurtosis & -.269 & .203 & -1.325 \\
& Kolmogorov Smirnov & & & .012 \\
\hline
\end{tabular}

Table 5 shows that Kolmogorov Smirnov value is $<.05$; for this reason, skewness-kurtosis values, Coefficient of Variability Value and descriptive statistics values are given in order to show the normality distribution. As a result of the analysis, skewness value is between -+ 3 values and the kurtosis value is between +-10 values. Considering the literature, Kline (2011) stated that normality tests can be applied if the normal distribution has a skewness value of \pm 3 and a kurtosis value of \pm 10 (Cited by: Zhang, Christine, \& Kunnan, 2014).

Table 6. Descriptive statistics and coefficient of variability values for EDS data

\begin{tabular}{|c|c|c|c|c|c|}
\hline & \multicolumn{5}{|c|}{ Research Group } \\
\hline & Mean & Median & Mode & SD & $\mathrm{V}$ \\
\hline EDS & 65.78 & 67.00 & 63 & 17.07 & 25.95 \\
\hline
\end{tabular}

The coefficient of variability value presented in Table 6 was taken into consideration to support normality and the $\mathrm{V}$ value was found as 25.95 for the data set. If the $\mathrm{V}$ value is $20<\mathrm{V}<25$, it means that the distribution is normal (Keklik et al., 2010: 640). The V value for this research was found at normality tendency. Besides, another factor supporting the normal distribution is the close values of mean and median. The proximity of these values is indicated in Table 7 and this proximity enhances the normality of the distribution. In this case, since the data were normally distributed, it was decided to conduct the parametric tests. For the second sub-problem of the study, independent samples t-test and one-way ANOVA were conducted. The homogeneity of variances was also investigated in order to apply these tests.

\subsection{Limitations}

The EDS scale used in the research was inspired by Dörnyei's study but developed in a way that contains items specific to English learning problems in Turkey. For this reason, this scale is developed with different items in different countries. However, it is known that there can be many different variables influencing demotivation (family, social circle, financial possibility, etc.). This scale is limited to measuring demotivation originating only from education life. 


\section{Results}

The demotivation level of high students was analyzed within the first sub-problem. It is seen in Table 7 that as a result of the descriptive statistical analysis, the arithmetic mean of the scores of the high school students' English demotivation scale was found as $\mathrm{X}=65.78$. According to Ünal \& Yanpar (2016), the lowest point that can be taken from the 20 -item scale is " 0 " and the highest score is " 100 ". The scores about demotivation can be interpreted as very low between 0 and 20, low between 21 and 40, medium between 41 and 60, high between 61 and 80 and very high between 81 and 100. It can be said in light of this information that the English demotivation levels of the high school students participating in the research are high. According to the analysis results, it is seen that students experience demotivation because of the teacher $(X=20.29)$, Lack of Interest in English and English Course $(X=19.00)$, Failure Experience $(X=9.56)$ and the classroom environment and course materials $(X=16.92)$. In addition, when Table 7 is examined, it is found that demotivation levels of the students for each sub-factor are above the average.

Table 7. Mean scores of EDS and sub-factors

\begin{tabular}{llllll}
\hline & $\mathrm{N}$ & Minimum & Maximum & Mean & Std. D. \\
\hline EDS & 579 & .00 & 100.00 & 65.78 & 17.075 \\
Teacher & 579 & .00 & 30.00 & 20.29 & 7.131 \\
Lack of Interest in English and English Course & 579 & .00 & 30.00 & 19.00 & 6.914 \\
Failure Experience & 579 & .00 & 15.00 & 9.56 & 3.736 \\
Classroom environment and course materials & 579 & .00 & 25.00 & 16.92 & 5.160 \\
\hline
\end{tabular}

It is analyzed in the second sub-problem whether the demotivation levels of the high students differ according to various variables. For that reason, t-test and one-way analysis of variance (ANOVA) were done for independent samples. The results of the t-test analysis for the independent samples for gender variable are given in Table 8 . The homogeneity of variance was examined with the Levene's test, and the values of $(F=.234 ; p>.05)$ were obtained for EDS. The Ho hypothesis was thus rejected. In other words, the hypothesis that the variances are not evenly distributed is rejected and the homogeneity of the variances is confirmed. Independent sample t-test analysis shows that there is a significant difference between EDS averages of female (Xfemale $=68.34$ ) and male (Xmale $=64.42)$ students $(\mathrm{t}=2.643, \mathrm{p}<.05)$. The analysis revealed that female students are more demotivated when compared to male students.

Table 8. Independent samples T-Test and variance homogeneity of groups

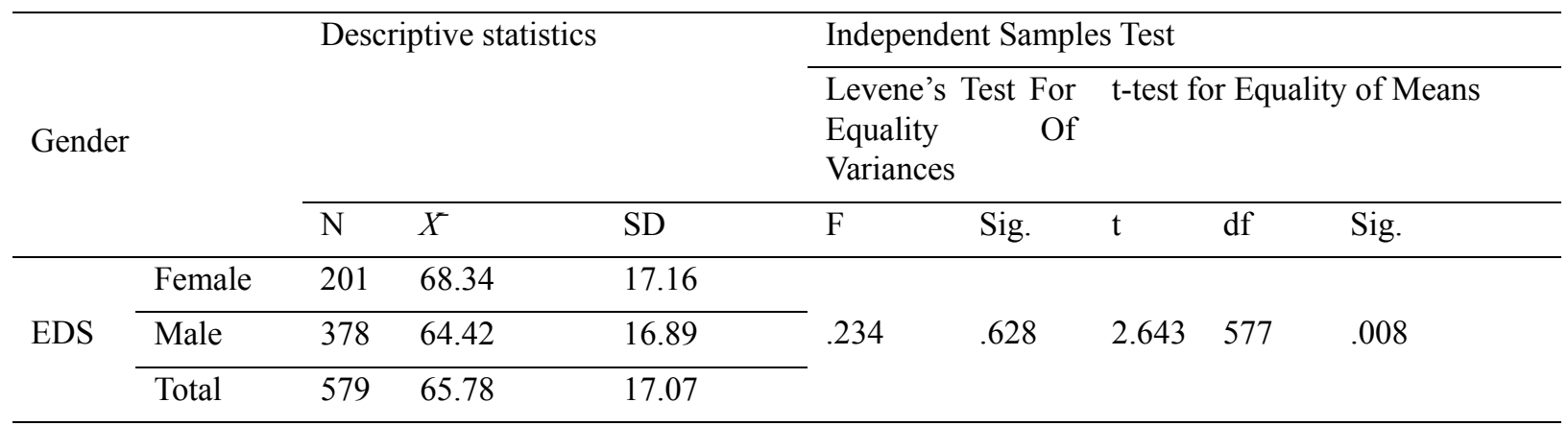

$* \mathrm{p}>.05$.

The results of the t-test analysis for the independent samples for type of high school variable are given in Table 9. The homogeneity of variance was examined with the Levene's test, and the values of $(F=.000 ; p>.05)$ were obtained for EDS. The Ho hypothesis was thus rejected. In other words, the hypothesis that the variances are not evenly distributed is rejected and the homogeneity of the variances is confirmed. Independent sample t-test analysis shows that there is a significant difference between EDS averages of GL (XGL=66.99) and VL $(X V L=62.82)$ students' $(\mathrm{t}=2.678, \mathrm{p}<.05)$. The analysis revealed that GL students are more demotivated when 
compared to VL students.

Table 9. Independent samples T-Test and variance homogeneity of groups

\begin{tabular}{|c|c|c|c|c|c|c|c|c|c|}
\hline \multirow{3}{*}{$\begin{array}{l}\text { Type } \\
\text { School }\end{array}$} & \multirow{3}{*}{ of High } & \multirow{2}{*}{\multicolumn{3}{|c|}{ Descriptive statistics }} & \multicolumn{5}{|c|}{ Independent Samples Test } \\
\hline & & & & & \multicolumn{2}{|c|}{$\begin{array}{l}\text { Levene's } \\
\text { Equality }\end{array}$} & \multicolumn{3}{|c|}{ (n) } \\
\hline & & $\mathrm{N}$ & $X$ & SD & $\mathrm{F}$ & Sig. & $\mathrm{t}$ & $\mathrm{df}$ & Sig. \\
\hline \multirow{3}{*}{ EDS } & $\begin{array}{l}\text { General } \\
\text { High } \\
\text { school }\end{array}$ & 412 & 66.99 & 16.99 & \multirow{3}{*}{, 000} & \multirow{3}{*}{.993} & \multirow{3}{*}{2.678} & \multirow{3}{*}{577} & \multirow{3}{*}{.008} \\
\hline & $\begin{array}{l}\text { Vocational } \\
\text { High } \\
\text { school }\end{array}$ & 167 & 62.82 & 16.96 & & & & & \\
\hline & Total & 579 & 65.78 & 17.07 & & & & & \\
\hline
\end{tabular}

$* \mathrm{p}>.05$.

One-way ANOVA analysis was done for the grade variable. The homogeneity test of the variances which is a prerequisite for One-Way ANOVA analysis is given in Table 10 and the analysis result is given in Table 11. The homogeneity of variance was examined with the Levene's test, and the values of $(\mathrm{LS}=1.46 ; \mathrm{p}>.05)$ were obtained for EDS and the homogeneity of the variances is confirmed. One-way ANOVA analysis shows that there is not a significant difference in EDS averages of students from different grades but the analysis reveals that $12^{\text {th }}$ grade students $(X 72$ th grade $=68.38)$ are the most de-motivated students and the de-motivation level of the students increases beginning from $9^{\text {th }}$ grade to $12^{\text {th }}$ grade.

Table 10. Test of homogeneity of variances

\begin{tabular}{llll}
\hline Levene Statistic & df1 & df2 & Sig. \\
\hline 1,463 & 3 & 575 &, 224 \\
\hline
\end{tabular}

Table 11. One-Way ANOVA analysis results

\begin{tabular}{|c|c|c|c|c|c|c|c|c|c|c|}
\hline \multirow[b]{2}{*}{ Grade } & & \multicolumn{3}{|c|}{ Descriptive statistics } & \multicolumn{6}{|c|}{ One-Way ANOVA } \\
\hline & & $\mathrm{N}$ & $X$ & SD & & $\begin{array}{ll}\text { Sum } & \text { of } \\
\text { Squares }\end{array}$ & df & $\begin{array}{l}\text { Mean } \\
\text { Square }\end{array}$ & $\mathrm{F}$ & Sig. \\
\hline \multirow{5}{*}{ EDS } & $9^{\text {th }}$ grade & 191 & 63.96 & 17.19 & \multirow{2}{*}{$\begin{array}{l}\text { Between } \\
\text { Groups }\end{array}$} & \multirow{2}{*}{1747.03} & \multirow{2}{*}{3} & \multirow{2}{*}{582.34} & \multirow{2}{*}{2.008} & \multirow[b]{2}{*}{.112} \\
\hline & $10^{\text {th }}$ grade & 141 & 64.82 & 18.06 & & & & & & \\
\hline & $11^{\text {th }}$ grade & 188 & 67.54 & 15.96 & $\begin{array}{l}\text { Within } \\
\text { Groups }\end{array}$ & 166777.26 & 575 & 290.04 & & \\
\hline & $12^{\text {th }}$ grade & 59 & 68.38 & 17.24 & Total & 168524.29 & 578 & & & \\
\hline & Total & 579 & 65.78 & 17.07 & & & & & & \\
\hline
\end{tabular}

One-way ANOVA analysis was conducted to find out in which level of education the students' demotivation decreases in English. The homogeneity test of the variances which is a prerequisite for One-Way ANOVA analysis is given in Table 12 and the analysis result is given in Table 13. The homogeneity of variance was examined with the Levene's test, and the values of $(\mathrm{LS}=2.104 ; \mathrm{p}>.05)$ were obtained for EDS and the homogeneity of the variances is confirmed. One-way ANOVA analysis shows that there is not a significant 
difference in EDS averages of students according to level of education but the analysis reveals that the students whose motivation begins to decrease at high school $(X=68.44)$ are the most de-motivated students.

Table 12. Test of homogeneity of variances

\begin{tabular}{llll}
\hline Levene Statistic & df1 & df2 & Sig. \\
\hline 2.104 & 2 & 421 & .123 \\
\hline
\end{tabular}

Table 13. One-Way ANOVA analysis results

\begin{tabular}{|c|c|c|c|c|c|c|c|c|c|c|}
\hline \multirow{2}{*}{\multicolumn{2}{|c|}{$\begin{array}{l}\text { Decrease } \\
\text { Motivation }\end{array}$}} & \multicolumn{3}{|c|}{ Descriptive statistics } & \multicolumn{6}{|c|}{ One-Way ANOVA } \\
\hline & & \multirow{2}{*}{$\begin{array}{l}\mathrm{N} \\
69\end{array}$} & \multirow{2}{*}{$\begin{array}{l}X \\
63.97\end{array}$} & \multirow{2}{*}{$\begin{array}{l}\text { SD } \\
18.56\end{array}$} & & $\begin{array}{l}\text { Sum } \\
\text { Squares }\end{array}$ & $\mathrm{df}$ & $\begin{array}{l}\text { Mean } \\
\text { Square }\end{array}$ & $\mathrm{F}$ & Sig. \\
\hline \multirow{4}{*}{ EDS } & Primary & & & & Between & \multirow{2}{*}{1253.541} & \multirow[b]{2}{*}{2} & \multirow{2}{*}{626.77} & \multirow{2}{*}{2,25} & \multirow{3}{*}{.106} \\
\hline & Middle & 163 & 65.73 & 16.07 & Groups & & & & & \\
\hline & $\begin{array}{l}\text { High } \\
\text { school }\end{array}$ & 192 & 68.44 & 16.46 & $\begin{array}{l}\text { Within } \\
\text { Groups }\end{array}$ & 117095.544 & 421 & 278.13 & & \\
\hline & Total & 424 & 66.67 & 16.72 & Total & 118349.085 & 423 & & & \\
\hline
\end{tabular}

The content analysis results of the qualitative data collected by the open-ended questionnaire form, frequency and percentage values and direct citations to present in-depth information are given in this part of the research. The content analysis of the responses of the students to the questions that are formed according to sub-factors of the scale and of the suggestions for the remotivation is presented in Table 14 and 15. When Table 14 is examined, it is seen that students experience demotivation for each subfactor and these demotivating factors influence the students in sub-theme related codes. The expression with the highest frequency value in each of the four sub-themes has been "decrease in motivation".

The students stated mostly as to the sub-theme of the inefficacy of instructional technologies and material use that the effectiveness of the lesson decreased and the lesson was difficult to understand. The expressions of two learners regarding this sub-theme are as follows: "Inability to use instructional technology and materials efficiently and correctly decreases our motivation. (S.17)" "Use of instructional technologies help students get adapted to the lesson but not employing them reduces our motivation. (S.34)" The students pointed out mostly for the sub-theme of their English teachers' attitudes and behaviors that the teachers 'teaching methods were not fun and that they fell into learned helplessness. The expressions of two learners regarding this sub-theme are as follows: "The behaviors of the teacher towards students influence whether we love the lesson more or not. (S.24)" "The fact that the teacher is tough and does not make the lesson fun decreases the motivation. (S.38)" Students often stated about the sub-theme of their lack of interest in English that they had a failure and problem in concentrating on the lesson. The expressions of two learners regarding this sub-theme are as follows: "I'm not interested in this lesson. That's why I have low motivation and I'm getting nervous. (S.6)" "I have little interest in English and this causes decrease in my motivation as well as failure. (S.11)" Students stated mostly as to the sub-theme of past failures in English courses that they developed a prejudice against English because of poor English background and thus their interest in English has declined. The expression of a learner regarding this sub-theme is as follows: "When I get a low mark in English, I don't feel like studying it. (S. 79)". 
Table 14. Content analysis of the responses of the students to the sub-theme questions ( $\mathrm{N}=84$ )

\begin{tabular}{|c|c|c|c|c|}
\hline Theme & Sub-Themes & Codes & $f$ & $\%$ \\
\hline \multirow{10}{*}{ 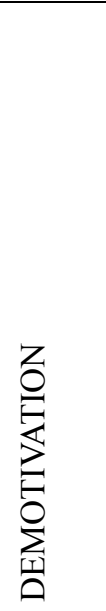 } & \multirow{5}{*}{$\begin{array}{l}\text { Inefficacy in instructional technologies and } \\
\text { material use }\end{array}$} & It decreases my motivation & 21 & 55.3 \\
\hline & & It reduces efficacy of course & 7 & 18.4 \\
\hline & & It makes understanding difficult & 7 & 18.4 \\
\hline & & Lessons are not fun & 3 & 7.9 \\
\hline & & Total & 38 & 100 \\
\hline & \multirow{7}{*}{ English teachers'attitudes and behaviors } & It decreases my motivation & 16 & 43.2 \\
\hline & & I can't learn by fun in lesson & 8 & 21.6 \\
\hline & & I fall into learned helplessness & 6 & 16.2 \\
\hline & & $\begin{array}{l}\text { It influences my future English } \\
\text { education }\end{array}$ & 3 & 8.1 \\
\hline & & It leads me into failure & 2 & 5.4 \\
\hline \multirow{12}{*}{ 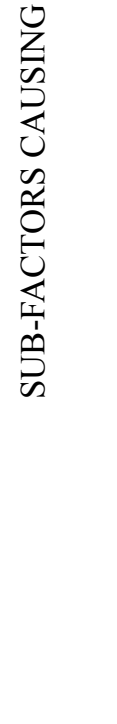 } & & I'm alienated from lesson & 2 & 5.4 \\
\hline & & Total & 37 & 100 \\
\hline & \multirow{5}{*}{ Students'lack of interest in English } & It decreases my motivation & 21 & 53.8 \\
\hline & & It leads me into failure & 8 & 20.6 \\
\hline & & It prevents me from concentrating & 6 & 15.4 \\
\hline & & It cause me to get bored quickly & 4 & 10.2 \\
\hline & & Total & 39 & 100 \\
\hline & \multirow{5}{*}{ Students'past failures in English courses } & It decreases my motivation & 14 & 38.8 \\
\hline & & $\begin{array}{l}\text { It makes me develop prejudice due } \\
\text { to poor English background }\end{array}$ & 10 & 27.7 \\
\hline & & It reduces my interest & 8 & 22.2 \\
\hline & & It results in learned helplessness & 4 & 11.3 \\
\hline & & Total & 36 & 100 \\
\hline
\end{tabular}

It is seen in Table 15 that students have produced solution proposals about way of teaching and use of technology for remotivation. Students expressed mostly as to the sub-theme of the way of teaching lesson that lessons should be made more entertaining, more time should be allocated for speaking skills and project-based activities should be employed. The expressions of two learners regarding this sub-theme are as follows: "If more visuals are used in English lessons and there is more fun in lessons, my motivation will increase and I like the lesson more. (S.44)" "We can listen to English songs once a week and the course can be more fun and enjoyable with various activities like this. (S.58)" Students stated mostly about the sub-theme of use of technology that films/videos must be watched in lessons and technology must be utilized more in the classroom. The expressions of two learners regarding this sub-theme are as follows: "In English lessons, subtitled English films should be watched to increase our motivation, and we develop our vocabulary this way and it helps us build a sentence. (S.48)" "Games like minecraft (a digital game) in English should be played in the lesson. We can listen to English songs once a week and the lesson can be more fun and enjoyable with various activities like this. (S.9)" 
Table 15. Content analysis of the suggestions of students for the remotivation $(\mathrm{N}=84)$

\begin{tabular}{|c|c|c|c|c|}
\hline Theme & Sub-Themes & Codes & $f$ & $\%$ \\
\hline \multirow{11}{*}{ 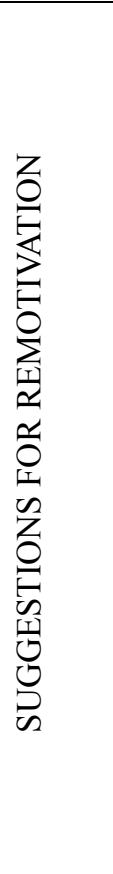 } & \multirow{6}{*}{ Way of teaching lesson } & Lesson must be fun & 20 & 44.4 \\
\hline & & $\begin{array}{l}\text { More time must be allocated to } \\
\text { speaking skills }\end{array}$ & 8 & 17.7 \\
\hline & & Project-based activities & 7 & 15.5 \\
\hline & & Visual materials must be used more & 5 & 11.1 \\
\hline & & $\begin{array}{l}\text { Lesson must be supplemented with } \\
\text { songs }\end{array}$ & 5 & 11.1 \\
\hline & & Total & 45 & 100 \\
\hline & \multirow{5}{*}{ Use of technology } & $\begin{array}{l}\text { Film/video must be watched in } \\
\text { lesson }\end{array}$ & 13 & 61.9 \\
\hline & & $\begin{array}{l}\text { Computer must be used more } \\
\text { efficiently }\end{array}$ & 5 & 23.9 \\
\hline & & $\begin{array}{l}\text { Interactive boards must be used } \\
\text { more effectively }\end{array}$ & 2 & 9.5 \\
\hline & & $\begin{array}{l}\text { Teaching based on digital game must } \\
\text { be practised }\end{array}$ & 1 & 4.7 \\
\hline & & Total & 21 & 100 \\
\hline
\end{tabular}

\section{Discussion}

Discussion on the results of the research is presented in a mixed method with quantitative and qualitative data, and for remotivation, on which the quantitative data collection tool is not focused, the responses given to the remotivation question added to the qualitative data collection tool are discussed. In this context, when quantitative data are examined, it is concluded that English demotivation levels of high students are high. When qualitative data are examined, students state that they experience demotivation and that the demotivating factors placed in quantitative data collection tool demotivate them. The sub-factors of particularly teacher, classroom environment and the use of course materials are emphasized both quantitatively and qualitatively. Meshkat \& Hassani (2012) wrote in their study that Iranian learners' demotivating factors in learning English were "Learning Contents and Materials" and "Teachers Competence and Teaching Styles". The results of this research support the results of the cited studies. When researches carried out in other countries (China, Iran, Pakistan, South Korea, Japan, etc.) are examined, the fact that students are demotivated to learn English is seen to a common factor. (Ali \& Pathan, 2017; Hojaji \& Salehi, 2017; Suzuki, 2017). However, it is known that there have been problems in English education in Turkey for many years. Even though students have been studying for years, they are unable to use basic four language skills effectively. Knowing when students are most likely to get demotivated may be a start for the solution to the problem. It was found in this study that the students experienced demotivation from primary school to high school and that they were mostly demotivated in high school. Furthermore, it was revealed that the students who became the most demotivated among the high school students were the 12th grade students. This can be interpreted as the loss of motivation as they progressed through their educational life. Kim and Seo (2012) found out in their study that among Korean elementary and high school EFL learners, for example, junior high school students' motivation was the weakest, and that the level of demotivation increased as the students advanced to a high school level and this research supports their research findings.

When examined in terms of gender variable, analyses show that female students have a significantly higher score of English demotivation than male students. One of the conclusions that Genc and Aydin (2017) reached in their research is that female learners tend to demonstrate significantly more positive attitudes toward learning English languiage than male students do. Unlike this result, it is concluded in this research that female students are more demotivated than male students. The reason for this can be interpreted that female students are more timid in spoken language than male students, they are more afraid of making mistakes in expressing themselves in the classroom and scared of being ridiculed. Qualitative data, supporting quantitative data, reveals that in-class 
environment is an important factor in the language learning process at the affective dimension. It is known that, in case of making mistakes, behaviours of other students like laughing, mocking, etc. are significant demotivating factors.

Analysis of the results regarding high school type variable shows that general high school students have a significantly higher score of English demotivation than the vocational high school students. The reason for this can be interpreted that the general high school students suffer university exam anxiety and have higher academic self-concepts compared to the vocational high school students, which influences their demotivation level. It can be regarded that the students of vocational high schools tend to feel more relaxed as they are directed to vocational courses rather than the cultural ones.

Another contribution of the mixed method is the qualitative collection and interpretation of data which cannot be obtained quantitatively. Both types of data show that the demotivation level of students is high; however, as the EDS scale does not contain the remotivation sub-dimension, a question was asked by the researcher in order to reveal the students' paths for remotivation. It was found that responses of students come under sub-themes of the way of teaching and use of technology. Students particularly put emphasis on more entertaining lessons and allocation of more time on speaking. The reason for this can be said to be the speaking skills that they are most challenged by. In addition, students stated that songs would also be an important tool for remotivation. Music and English songs are something that students like listening and enjoy while learning. They can be thought to refer to learning by doing and experience. One of the proposed paths for remotivation is the need for more efficient use of technology within the classroom. Kim (2010) concluded in his study that mass media and the Information Technology (IT) infrastructure play a crucial role in EFL motivation and attitudes among Korean high school students. In addition to this, Genc (2009) revealed in his research that foreign language learning seemed to be affected by different technological equipment such as computers, projectors, video, films, internet, e-learning and multi-media. Students' responses have showed that there is great relation between language-learning motivational factors and using technology. In this research, the students emphasized the importance of technology in searching paths from demotivation to remotivation and that the use of technology is an important remotivator, which supports the findings of these two researches. Moreover, one of the most important reasons for these students' expressions of technology is that they are of zero generation. This generation is largely in contact with information technology (IT), mobile devices and the Internet. Therefore, it can be considered that they present the effective use of technology as a remotivating factor in English classes as in the other courses.

\section{Conclusion}

It was revealed as a result of the research that high school students' English demotivation levels are higher and female students have a higher demotivation score than male students. When the school type and grade level are examined, it is seen that general high school students experience more demotivation than vocational high school students while $12^{\text {th }}$ grade students suffer it more than other grade levels. In addition, students expressed about remotivation that lessons should be more fun, more time should be spent on speaking skills, and especially, effective use of technology in the English learning-teaching process would be key to remotivation. According to Kaivanpanah and Ghasemi (2011), demotivation does not imply total loss of learners' motivation. In fact, the positive influences that make up motivational basis can still be there and positive motives may still be active in a learner's learning process. This research reveals that there is a problem, and motivational processes that are in students but awaiting need to be triggered to overcome this problem. In this context, the following suggestions have been developed for the remotivation of demotivated students:

1). It can be suggested that, in the process of developing an English language curriculum, learning-teaching processes can be developed as entertaining, collaborative and experiential learning based on the fact that language courses have a different learning-teaching process than other courses.

2). Contents that relate to the immediate lives of the students and focus on four basic language skills separately, should be developed and organized to attract the attention of the students. Moreover, coursebooks can be supplemented via e-content, 2d-code and augmented reality applications.

3). Regarding the use of technology, teachers should decide which technology-based applications to use upon interviews with students, and students can be suggested to prefer applications in which they can practise linguistically effective communication and learn by fun.

4). Virtual environments should be developed through internet support to improve students' speaking skills in particular outside the classroom. Teachers can be suggested to use applications like e-twinning effectively in order to enable students to communicate with students in other English-speaking countries. 
5). Students can be remotivated via performance and project assignments so that they can avoid the negative effects of their past failure in English course on their current English learning process.

Suggestions for future researchers are below as follows:

1). The English demotivation of students through time can be examined by designing a longitudinal research in the same group of students beginning with primary school.

2). The effect of family on the English demotivation of students can be investigated.

3). The specific impact of English computer games and music/song-supported language teaching can be researched for the English remotivation.

4). The effect of language teaching methods on demotivation can be investigated via experimental researches.

\section{References}

Acat M. B., \& Demiral, S. (2002). Türkiye'de yabancı dil öğretiminde motivasyon kaynakları ve sorunları, Kuram Ve Uygulamada Eğitim Yönetimi, 31, 312-324.

Al-Sharief, S. (2013). The interplay of motivation and demotivation: The case of EFL learners majoring in English. International Journal of Applied Linguistics \& English Literature, 2(1), 53-59. https://doi.org/10.7575/ijalel.v.2n.1p.53

Ali, M. S., \& Pathan, Z. H. (2017). Exploring factors causing demotivation and motivation in learning English language among college students of Quetta, Pakistan. International Journal of English Linguistics, 7, 2. https://doi.org/10.5539/ijel.v7n2p81

Birinci, K. K. (2015). An investigation into the motivation of English language teachers in Turkey with a focus on the effect of motivational aspects on their teaching. (Master Thesis). Karadeniz Technical University, Trabzon, Turkey.

Butt, A., Khosa D., Malghani, M., Khosa, M., \& Bukhari R. (2016). Perceptions of English medium and non-English medium students regarding demotivation in learning English as foreign language. IJASOS-International E-Journal Of Advances In Social Sciences, 3(5), 530-537.

Challa, V. R. (2015). Affect of motivation and demotivation factors in second language learning, Research Journal Of English Language And Literature (RJELAL), 3, 244-248.

Cheon, S. H., \& Reeve, J. (2015). A classroom-based intervention to help teachers decrease students'amotivation. Contemporary Educational Psychology, 40, 99-111. https://doi.org/10.1016/j.cedpsych.2014.06.004

Creswell, J. W. (2015). A concise introduction to mixed method research. Thousand Oaks, CA: SAGE Publications.

Dörnyei, Z. (1998). Motivation in second and foreign language learning. Language Teaching, 31, 117-135. https://doi.org/10.1017/S026144480001315X

Dörnyei, Z. (2001). Motivational strategies in the language classroom. New York: Cambridge University Pres. https://doi.org/10.1017/CBO9780511667343

Dörnyei, Z., \& Ushioda, E. (2011). Teaching and researching motivation. In C. N. Candlin, \& D. R. Hall (Eds.), Applied linguistics in action series, (2nd ed.) Great Britain: Pearson Education Limited.

Falout, J., Elwood, J., \& Hood, M. (2009). Demotivation: Affective states and learning outcomes, System, 37, 403-417. https://doi.org/10.1016/j.system.2009.03.004

Falout, J. (2012). Coping with demotivation: EFL Leartners' Remotivation Processes, The Electronic Journal For English as a second or foreign language, 16(3), 1-29.

Gardner, R. C. (1985). The social psychology of language 4, Edited by Howard Giles. Great Britain: Edward Arnold Publishing.

Genc İlter B. (2009). Effect of technology on motivation in EFL classrooms, Turkish Online Journal Of Distance Education, 10(4).

Genc, Z. S., \& Aydın, F. (2017). An analysis of learners' motivation and attitudes toward learning English language at tertiary level in Turkish EFL context. English Language Teaching, 10(4), http://doi.org/10.5539/elt.v10n4p35

Gökdemir, C. V. (2005). Üniversitelerimizde verilen yabancı dil öğretimindeki başarı durumumuz. AtatürkÜniversitesi Sosyal Bilimler Enstitüsü Dergisi, 6(2). 
Guiemi, X. (2015). From motivation to demotivation and then to remotivation: A new path of study on motivation research. Foreign Language Education, 2.

Hassaskhah, J., Zafarghandi, A. M., \& Fazeli, M. (2015). Reasons for demotivation across years of study: Voices from Iranian English major students. Educational Psychology, 35(5), 557-577. https://doi.org/10.1080/01443410.2014.893557

Haznedar, B. (2010). Türkiye'de yabancı dil eğitimi: Reformlar, yönelimler ve öğretmenlerimiz. International Conference on New Trends in Education and Their Implications. 11-13 November, Antalya-Turkey.

Hirvonen, M. (2010). Demotivation in learning English among immigrant pupils in the ninth grade of comprehensive school. (A Pro Gradu Thesis). University of Jyvasklya, Jyvasklya, Finland.

Hojaji, N., \& Salehi, H. (2017). Examining Iranian EFL teachers' demotivating factors: Years of teaching experience in focus. International Journal of Foreign Language Teaching \& Research, 5, 17.

Işık, A. (2008). Yabancı dil eğitimimizdeki yanlışlar nereden kaynaklanıyor?, Journal of Language and Linguistic Studies, 4, 2.

Jahedizadeh, S., Ghanizadeh, A., \& Ghonsooly, B. (2016). The role of EFL learners' demotivation, perceptions of classroom activities, and mastery goal in predicting their language achievement and burnout. Asian-Pacific Journal of Second and Foreign Language, 1(16), 1-17. https://doi.org/10.1186/s40862-016-0021-8

Kaivanpanah, S., \& Ghasemi Z. (2011). An investigation into sources of demotivation in second language learning Iranian. Journal of Applied Linguistics (IJAL), 14(2), 89-110.

Keklik, İ., Yurtseven, M., Uygar, İ., Çiçek, S., Doğan, N., \& Demir, T. (2010). KPSS eğitim bilimleri hızlı bakış. Ankara: Ayrıntı Basımevi.

Kim, S. (2015). Demotivation and L2 motivational self of Korean college students. English Teaching, 70(1), 29-55. https://doi.org/10.15858/engtea.70.1.201503.29

Kim, T. Y. (2010). Socio-political influences on EFL motivation and attitudes: comparative surveys of Korean high school students. Asia Pacific Education Review, 11, 211-222. https://doi.org/10.1007/s12564-010-9071-7

Kim, T. Y., \& Kim, Y. K. (2015). Elderly Korean learners' participation in English learning through lifelong education: Focusing on motivation and demotivation. Educational Gerontology, 41, 120-135. https://doi.org/10.1080/03601277.2014.929345

Kim, T. Y., \& Seo, H. S. (2012). Elementary school students' foreign language learning demotivation: A mixed methods study of Korean EFL context. The Asia-Pacific Education Researcher, 2(1), 160-172.

Li, C., \& Zhou, T. (2017). A questionnaire-based study on Chinese university students' demotivation to learn English. English Language Teaching, 10(3). https://doi.org/10.5539/elt.v10n3p128

Meshkat, M., \& Hassani, M. (2012). Demotivating factors in learning English: The case of Iran. Procedia -Social and Behavioral Sciences, 31, 745-749. https://doi.org/10.1016/j.sbspro.2011.12.134

Mirza, Q., Khatoon, S., \& Lohar, S. A. (2016). Demotivation in ESL class at university level: A study of Mehran University of engineering and technology. Jamshoro International Research Journal of Arts and Humanities, 44, 169-181.

Mohammadi, M. (2014). The pathology of demotivation and amotivation in English language learning context: A case study. Scientific Information Database, Retrieved from http://www.sid.ir/en/VEWSSID/J_pdf/134820140402.pdf

Muhonen, J. (2004). Second language demotivation: Factors that discourage pupils from learning the English language. (A Pro Gradu Thesis). University of Jyvasklya, Jyvasklya, Finland.

Nicholson, J. S. (2013). Influencing motivation in the foreign language classroom, Journal of International Education Research, 9(3), 277-286. https://doi.org/10.19030/jier.v9i3.7894

Okon, K. (2014). Teaching English effectively, with special focus on learners' interest. Hamburg: Anchor Academic Publishing.

Paker, T. (2012). Türkiye'de neden yabancı dil (İngilizce) öğretemiyoruz ve neden öğrencilerimiz iletişim kurabilecek düzeyde İngilizce öğrenemiyor? Pamukkale University Journal of Education, 32, 89-94. https://doi.org/10.9779/PUJE563 
Rashidi, N., Rahimi, M., \& Alimorad, Z. (2014). Iranian university English learners' discursive demotivation construction. Iranian Journal of Language Teaching Research, 2(2), 35-49.

Sahragard, R., \& Ansaripour, E. (2014). Demotivating and remotivating factors among MA students of TEFL: An Iranian case. International Journal of Society, Culture \& Language, 2(1), 88-105.

Song, B., \& Kim, T. Y. (2017). The dynamics of demotivation and remotivation among Korean high school EFL students. System, 65, 90-103. https://doi.org/10.1016/j.system.2016.12.010

Sundqvist, P., \& Olin-Scheller, C. (2013). Classroom vs. extramural English: Teachers dealing with demotivation. Language and Linguistics Compass, 7(6), 329-338. https://doi.org/10.1111/lnc3.12031

Suzuki, S. (2017). Emerged challenges for English education in Japan: The emotional baggage of language learners. Apples - Journal of Applied Language Studies, 11(1), 5-11. https://doi.org/10.17011/apples/urn.201702061368

Trang, T. T., \& Baldauf, R. B. (2007). Demotivation: Understanding resistance to English language learning -The case of Vietnamese students. The Journal of Asia TEFL, 4(1), 79-105.

Unal, K., \& Yanpar, Y. T. (2016). Turkish students' demotivation to study English: A scale development. Croatian Journal of Education, 18(3), 755-777. https://doi.org/10.15516/cje.v18i3.1661

Ushioda, E. (1998). Effective motivational thinking: A cognitive theoretical approach to the study of language learning motivation. In E. S. Alcón, \& E. Codina (Eds.), Current issues in English language methodology. Castelló de la Plana, Spain: Publicacions de la Universitat Jaume.

Ushioda, E. (2002). Language learning at university: Exploring the role of motivational thinking. In Z. Dörnyei, $\&$ R. Schmidt (Eds.), Motivation and second language acquisition, USA: Hawai National Foreign Language Resources Center.

Zhang, L. M., Christine, C. M., \& Kunnan, A. J. (2014). Analysis of test takers' metacognitive and cognitive strategy use and EFL reading test performance: A multi-sample SEM approach. Language Assessment Quarterly, 11(1), 76-102. https://doi.org/10.1080/15434303.2013.853770

\section{Copyrights}

Copyright for this article is retained by the author(s), with first publication rights granted to the journal.

This is an open-access article distributed under the terms and conditions of the Creative Commons Attribution license (http://creativecommons.org/licenses/by/4.0/). 